\title{
THE VALUE-RELEVANCE OF INTANGIBLES: THE CASE OF SOFTWARE CAPITALIZATION
}

by

David Aboody and Baruch Lev

September 1998 


\section{THE VALUE-RELEVANCE OF INTANGIBLES: THE CASE OF SOFTWARE CAPITALIZATION}

\section{Introduction}

We examine the relevance to investors of information on the capitalization of software development costs, in accordance with Financial Accounting Standards Board Statement No. 86 (SFAS 86). ${ }^{1}$ Software capitalization, the only exception in the U.S. to the full expensing rule of R\&D (SFAS 2), pertains to the development component of R\&D. It therefore provides a laboratory experiment for an accounting treatment of intangibles that differs from the nearly-universal full expensing of intangible assets. ${ }^{2}$ Our examination of the 10 -year record of SFAS 86 is also motivated by the 1996 petition from the Software Publishers Association (SPA) to abolish the standard. The FASB has indicated (“Action Alert," August 28, 1996) that it will consider the petition.

The major claim put forward by the SPA is that, given industry changes since 1986, capitalization of software development costs does not benefit investors:

The rationale underlying the capitalization of software development costs is to recognize the existence of an asset of the corporation. However, an asset should be recognized.... only if ultimate realization of the asset is reasonably assured ... Due to factors such as the ever-increasing volatility in the software marketplace, the compression of product cycles, the heightened level of competition and the divergence of technology platforms, realization of software assets has become increasingly uncertain even at the point of technological feasibility.... We do not believe that software development costs are a useful predictive factor of future product sales. (SPA March 14, 1996 letter, p.4).

To bolster their claim, the Software Publishers Association invokes investors' attitudes toward "soft assets":

The members of the SPA CFO Committee, ... have indicated the substantial majority of their investors, underwriters, and financial analysts believe financial reporting by software companies is improved when all software development costs are charged to 
expense as incurred. These users of financial statements do not believe the recording of a "soft" asset for the software being developed is particularly relevant and does not aid the user of financial statements. The users of financial statements... have a high degree of skepticism when it comes to soft assets resulting from the capitalization of software development costs. (SPA, March 14, 1996 letter, p.5).

Thus, the Software Publishers Association concludes:

Financial reporting and financial statements would be more reliable and consistent if all software development costs were required to be charged to expense.

We examine the relevance to investors of public information on software capitalization by analyzing both associations of financial data with capital market observables and earnings forecast accuracy. We also provide evidence on potential motives underlying the software industry's petition to abolish SFAS 86, and the apparent endorsement of this petition by some financial analysts. This petition raises intriguing interest group questions, since software capitalization was strongly supported in 1985 by the then trade group of software companies -- ADAPSO (The Association of Data Processing Service Organizations). ${ }^{3}$ The shift in attitudes toward capitalization is particularly puzzling given the flexibility of SFAS 86, which largely enables those who wish to capitalize to do so and others to immediately expense software developments costs. Analysts' objection to capitalization is equally intriguing, since software capitalization can be easily undone by subtracting the periodic capitalization figure from reported earnings and the capitalized software asset from total assets and equity. At best, capitalization is informative about the success of software development programs and at worst the information can be ignored.

For a sample of 163 firms during the period 1987-1995, we find that annually capitalized development costs are positively associated with stock returns and the cumulative software asset reported on the balance sheet is associated with stock prices. Furthermore, software capitalization data are associated with subsequent reported earnings, indicating another dimension of relevance to investors. We find no support for the view that the judgment involved in software capitalization decreases the quality of reported earnings. Finally, we document a significant association between 
development costs which were fully expensed by firms not following SFAS 86 and subsequent stock returns, consistent with a delayed investor reaction to product development of these companies.

In probing the reasons for the software producers' change in attitude towards the capitalization of software development cost, we document a significant mid-1990's shift in the impact of software capitalization on reported earnings and return-on-equity of software companies. Whereas in the early period of SFAS 86 application (mid- to late-1980s) software capitalization increased reported earnings more than the decrease in earnings by the amortization of the software asset (since that asset was still small), during the early 1990s the gap between the earnings impacts of capitalization and amortization narrowed, and in 1995, the capitalization and amortization positive and negative effects were roughly offsetting. This impact on reported performance may have been among the reasons underlying the SPA's petition to abolish SFAS 86. Analysts' objection to capitalization may be related to the random element introduced by capitalization to reported earnings which, in turn, complicates the forecasting task. Indeed, we find that analysts' earnings forecast errors are positively associated with the intensity of software capitalization.

Our evaluation of the 10 -year record of software capitalization in the U.S. is timely given the current interest in accounting for intangibles. For example, the FASB has recently established a Task Force on Business Combinations to examine, among other things, the accounting treatment of acquired intangibles, some of which (R\&D-in-process) are immediately expensed by acquirers (Deng and Lev 1998). ${ }^{4}$ Also, the Accounting Standards Executive Committee of the AICPA (AcSEC) released in March 1998 a Statement of Position on accounting for software for internal use (SFAS 86 , the focus of this study, deals with software intended for sale), calling for the capitalization of certain development costs in a similar manner to SFAS 86. Abroad, the International Accounting Standards Committee (IASC) is about to issue Standard No. 38 on intangibles which calls for the capitalization of internally developed intangibles with identifiable benefits (IASC, 1998). While SFAS 86 deals only with the capitalization of post-feasibility development costs, an assessment of the record of SFAS 86 should benefit the reexamination of accounting for intangibles. 


\section{Sample Selection and Summary Statistics}

The initial sample for this study was the 463 firms on the 1995 Compustat Industrial and Research files classified as computer programming and prepackaged software (SIC codes 7370-7372). We excluded 130 firms with fewer than three years of existence as a public company during 19871995, to accommodate certain tests which require limited time-series data (e.g., for computing twoyear lagged changes in earnings). Eighty firms of the 130 deleted had an initial public offering in 1994 or 1995, while the remaining 50 were acquired or ceased to operate after fewer than three years as a public company. ${ }^{5}$ We also excluded 64 firms which were not engaged in developing software products and 56 firms (primarily non-US registrants) with no price or return data on the 1995 CRSP database. Finally, we deleted 30 firms for which no or only one financial statement could be located on Laser Disclosure or Lexis/Nexis (from which we obtained information missing from Compustat), as well as 20 firms which reported only purchased software, or for which information pertaining to internally developed software could not be separately identified. The final sample consists of 163 software companies

We used both the Current and Research Compustat tapes to avoid survivorship bias. For example, a firm that was publicly traded during 1987-1990 but failed in 1991 will be included in the sample. A minor survivorship bias, however, may have been introduced by excluding firms with less than three years of data, which eliminates from the sample recent (1994 and 1995) IPOs.

Because Compustat generally aggregates the capitalized software asset with other assets and includes the related amortization with cost of sales, we obtained the financial statements of the sample companies from Laser Disclosure and Lexis/Nexis databases. We collected the following data: net capitalized software asset, the annual software development expense, the annual capitalized software amount, the annual amortization of the software asset, and the occasional write-offs of capitalized software. ${ }^{6}$

Table 1 provides summary statistics for the sample companies. ${ }^{7}$ The sales and total assets figures indicate that over the examined period (1987-95) software companies, on average, quadrupled in size (doubling at the median). For both sales and total assets, the means are substantially larger 
than the medians, indicating that the sample includes a small number of very large companies. The increasing sample size $(\mathrm{N})$ indicates that the software industry has not yet gone through a "shakeout period," typical of maturing industries, where the number of firms grows quickly during an initial stage, which is followed by a fast decline (shakeout) and stabilization of the number of competitors. ${ }^{8}$

\section{TABLE 1 HERE}

The return on equity (ROE) figures in Table 1 indicate that the median sample ROE ranged between 10 and 20 percent during 1987-1992, decreasing to 8-15 percent in 1993-95 (the mean ROE fluctuates widely because of a few outliers). ${ }^{9}$ The reduced ROE figures in recent years, reflecting intensified competition and continued entry, are yet another indication that the software industry has not reached maturity. The steadily increasing market-to-book ratio, at both the mean and the median, indicates that investors' growth expectations of the software industry keep rising. The median debt-to-equity ratios are very small, yet at the mean, a software company has roughly a 5:1 capitalization ratio, at book values.

Capitalization intensity (the annually capitalized portion of software development costs divided by total development costs, expensed as well as capitalized) -- is among the key variables we examine. Both the mean and median values are stable at 25-30 percent through 1992 and decline thereafter. This apparent sharp decline of capitalization intensity is mainly driven by recent entrants to the industry, who tend to capitalize less than older companies. For example, in 1987, sample firms that were publicly traded for two years or less had a mean (median) capitalization intensity of $30 \%(27 \%)$, whereas in 1995 , similarly young firms had a mean (median) capitalization

intensity of $7.9 \%(0 \%){ }^{10}$ In contrast, mature sample firms that were public for at least 8 years had a stable mean capitalization ratio of 23\% throughout the 1987-1995 period, while their median capitalization intensity decreased from $18 \%$ to $15 \%$.

Young companies may have low capitalization intensities because most of their software development efforts have not yet reached the technological feasibility stage required for capitalization (see appendix). Alternatively, analysts' frequent claims that software capitalization “contaminates" financial reports and reduces earnings quality may have a stronger effect on young 
firms trying to establish reporting credibility than on mature companies. Analysts' skepticism concerning capitalization may have also induced some profitable mature firms to curtail capitalization. Nevertheless, despite the recent decline in capitalization intensity, many software companies still capitalize a substantial portion of development costs, as evidenced by the fact that the top quartile of the sample firms (ranked by capitalization) had in 1995 a median capitalization intensity of $48 \%$.

\section{Distinguishing "Capitalizers" from "Expensers"}

Since SFAS 86 affords considerable implementation flexibility to software companies, it is important to distinguish at the outset between software capitalizers and immediate expensers. ${ }^{11}$ Doing so sheds light on whether capitalization is practiced by underperforming companies to enhance their reported earnings and provides control variables.

Since SFAS 86 conditions capitalization on the technological aspects of software development (e.g., the "product design" or a "working model" must be completed prior to capitalization), economic factors underlying software development may influence the decision to capitalize or expense. For example, immediate expensing may be suitable for products with a short development period, while capitalization fits products developed over several years. Since the specifics of firms' production functions are difficult to identify from public information, we proxy for them by categorizing the sample firms by the type of products developed. We adopt the four software product types (or industry subdivisions) used in the Deloitte and Touche [1996] annual survey: engineering, education and entertainment, business applications, and PC packaged software. $^{12}$

We then categorized as "expensers" firms that immediately expensed all of their software development costs; and as "capitalizers" those that capitalized a portion of those costs. Of the 163 sample firms, 34 expensed all of their development costs in every sample year, and 102 firms capitalized a portion of their development costs every year. Fifteen firms capitalized development costs in all but one year, and were classified as "capitalizers". Twelve companies that expensed in 
one period and capitalized in the other were classified as "expensers" in the period they expensed and "capitalizers" in the period they capitalized. ${ }^{13}$

Our classification of sample firms by product-type and accounting policy (capitalization versus full expensing) indicates that engineering is the only product-type where nearly all firms (96.7\%) capitalize development costs. However, this product-type constitutes only $7.1 \%$ of the sample observations. In the other product-type (education and entertainment, business applications, and PC packaged software) Between 65 and 80 percent of the firms capitalize development costs and a pairwise significance tests for the differences between the number of "capitalizers" and "expensers" across the product-types failed to reveal statistically significant differences (at the 0.05 level). We therefore conclude that product-type does not systematically discriminate between "capitalizers" and “expensers". To distinguish between "capitalizers" and "expensers", we considered attributes derived from the debate which surrounded the 1985 software capitalization exposure draft (FASB: Public Record, 1985), where conjectures concerning why, when and who will expense or capitalize development costs were advanced. Following are the examined discriminating candidates:

1. Firm Size, measured as the log of market value of equity three months after fiscal yearend. Large firms tend to spend a substantial part of software development costs on basic research and on maintenance and upgrades of their products. These costs are expensed according to SFAS 86 (see appendix), and consequently, large firms are expected to expense a larger share of development costs than smaller firms.

2. Software Development Intensity, measured by the ratio of annual software development costs to sales. To the extent that economies of scale characterize the software industry, firms which spend more on software development will experience, on average, a higher success rate in developing products, leading to a larger capitalization share. Accordingly, we expect a positive association between development intensity and capitalization rate.

3. Profitability, measured by net income converted to full expensing (i.e., income plus software amortization, minus the annually capitalized software) divided by sales. Given analysts' skepticism about software capitalization, it is widely believed that profitable 
companies avoid capitalization in order not to taint the perceived quality of their earnings in analysts' eyes.

4. Leverage, measured by long-term debt divided by book value of equity (minus the software assets). Leverage is a proxy for the restrictiveness of loan covenants as motivators of capitalization; firms closer to loan restrictions may favor capitalization which increases equity and earnings.

5. Systematic Risk, or $\beta$. Basic research is in general riskier than product development.

Basic research is also expensed according to SFAS 86, while product development is capitalized. Thus, riskier firms, namely those devoting a larger share of development efforts to basic research, can be expected to expense more than less risky companies.

Table 2 reports coefficient estimates from a regression of capitalization intensity (scaled by market value) on these five firm-specific attributes. ${ }^{14}$ The four variables found to be statistically significant at the 0.01 level are: size (log of market value), firm profitability, software development intensity, and leverage (the latter is significant at the 0.05 level). The signs of the significant coefficients are in the expected direction, indicating that smaller, less profitable, more leveraged firms, and those with a higher ratio of development costs to sales (development intensity) tend to capitalize more of their software development costs. Accordingly, we control in subsequent tests for those variables by including in the regressions the predicted value of the discriminating regression. ${ }^{15}$

\section{TABLE 2 HERE}

\section{Is Software Capitalization Value-Relevant?}

"Sophisticated investors will discount the earnings of software developers by the amount of capitalized development expense. The financial and investment community will discount the assets of software developers to limit the risk that balance sheets contain assets whose values are overstated. Only unsophisticated investors will be fooled." (Systematics, Inc., letter to the FASB, November 13, 1984, on behalf of nine major software producers). 
This letter claims that that the relevance of software capitalization ranges from the nonexistent (to sophisticated investors) to the negative (for the unsophisticated). We examine the value-relevance of software capitalization using three approaches: associating stock returns with contemporaneous financial data, associating prices with financial data, and examining the predictiveability of capitalization data with respect to subsequent earnings.

\subsection{ANNUAL CAPITALIZATION DATA AND STOCK RETURNS}

An association between unexpected capitalization-related items and contemporaneous annual stock returns indicates the extent to which the information contained in software capitalization is consistent with that used by investors (such an association test cannot, of course, indicate whether investors actually used capitalization data in assessing security values). We estimate the following cross-sectional regression:

$\mathrm{R}_{\mathrm{it}}={ }_{\mathrm{Y}=87}^{95} \beta_{0 \mathrm{Y}} \mathrm{YR}_{\mathrm{it}}+\beta_{1} \Delta \mathrm{CAP}_{\mathrm{it}}+\beta_{2} \Delta \mathrm{EXP}_{\mathrm{it}}+\beta_{3} \Delta \mathrm{EXPCAP}_{\mathrm{it}}+\beta_{4} \Delta \mathrm{AMRT}_{\mathrm{it}}+\beta_{5} \mathrm{X}_{\mathrm{it}}^{\mathrm{a}}+\beta_{6} \Delta \mathrm{X}_{\mathrm{it}}^{\mathrm{a}}+$

$\beta_{7} \mathrm{CAPPRE}_{\mathrm{it}}+\varepsilon_{\mathrm{it}}$

where: $\mathrm{R}_{\mathrm{it}}$ is the firm's annual stock return, cumulated from nine months before fiscal t year-end through three months after it; $\Delta \mathrm{CAP}_{\text {it }}$ is the annual change in the capitalized amount of software development costs; $\Delta \mathrm{EXP}_{\mathrm{it}}$ is the annual change of software development expenses of "expensers";

$\triangle$ EXPCAP $_{\text {it }}$ is the annual change of the software development expense of "capitalizers". (For "capitalizers", the annual amount capitalized $\left(\mathrm{CAP}_{\text {it }}\right)$ plus the amount expensed $\left(\mathrm{EXPCAP}_{\text {it }}\right)$ equals the annual software development costs). $\triangle \mathrm{AMRT}_{\mathrm{it}}$ is the annual change in the amortization of the software asset for "capitalizers". $X_{\text {it }}^{\mathrm{a}}$ is the adjusted (pre-software development items) annual net income of firm i in year $t$ (i.e., reported income plus the software development expense and the

amortization of the software asset). $\Delta^{X_{i t}^{a}}$ is the annual change in adjusted net income. $\mathrm{YR}_{\mathrm{it}}$ is a time indicator variable that equals one if an observation is from fiscal year Y (as defined by Compustat), 
and zero otherwise. All right-hand variables (except $\mathrm{YR}_{\mathrm{it}}$ and CAPPRE $\mathrm{it}_{\mathrm{it}}$ ) in expression (1) are scaled by beginning of fiscal year market value. The annual change form of the software variables in (1) proxies for the unexpected values of these variables.

The variable CAPPRE $_{i t}$ in expression (1) is the predicted value for each firm-year obtained from the regression of software capitalization intensity on the five company attributes described in the preceding section (and defined in Table 2). We include this predicted value in regression (1) to control for company attributes systematically associated with the capitalization decision.

We applied the incremental information test suggested in Biddle et al. [1995] to expression (1). We therefore test the incremental informativeness (with respect to stock returns) of the level and changes of the independent variables. The test indicated that for capitalized software (CAP), expensed development costs of "expensers" (EXP), and expensed costs of "capitalizers" (EXPCAP), the annual changes of the variables are incrementally informative at better than the 0.10 level, whereas the levels of those variables are not informative. With respect to the annual amortization (AMRT), the test indicated that both level and changes are relevant. However, the level and the change of AMRT are highly correlated, so that we found it advisable to report regression results based on the change in AMRT. ${ }^{16}$ With respect to earnings, the Biddle test indicated that both the level and changes were incrementally informative, consistent with the findings of Easton and Harris [1991] and Ohlson and Shroff [1992]. Accordingly, expression (1) includes the level and annual change of adjusted earnings.

If the change in annually capitalized development costs ( $\triangle \mathrm{CAP})$ represents value-relevant information to investors, then $\beta_{1}$ in (1) should be positive. Since EXP and EXPCAP (the total development costs of "expensers" and the portion of annual development costs expensed by “capitalizers", respectively) likely include development expenditures incurred before technological feasibility has been achieved, we predict both $\beta_{2}$ and $\beta_{3}$ to be positive but smaller than $\beta_{1}$. Our reasoning is that while firms will generally undertake positive expected value projects, achieving technological feasibility (indicated by capitalization) confirms to investors that the project has a 
positive expected value. We predict $\beta_{4}$ to be negative as it captures the unexpected decline in value of the software asset. Based on previous findings, $\beta_{5}$ and $\beta_{6}$ are predicted to be positive.

\subsection{THE SOFTWARE ASSET AND SHARE PRICES}

Expression (1) examines the value-relevance of the annual capitalized development costs. To examine the value-relevance (in the association sense) of the cumulative software asset presented on the balance sheet, we used the following regression:

$$
\mathrm{P}_{\mathrm{it}}={ }_{\mathrm{Y}=87}^{95} \beta_{0 \mathrm{Y}} \mathrm{YR}_{\mathrm{it}}+\beta_{1} \mathrm{EPS}_{\mathrm{it}}+\beta_{2} \mathrm{BVPS}_{\mathrm{it}}^{\mathrm{a}}+\beta_{3} \mathrm{CAPSOFT}_{\mathrm{it}}+\varepsilon_{\mathrm{it}}
$$

where, $\mathrm{P}_{\mathrm{it}}$ is firm i's stock price three months after fiscal year end; EPS $_{\mathrm{it}}$ is reported annual earnings

per share; $\mathrm{BVPS}_{\mathrm{it}}^{\mathrm{a}}$ is the book value of equity per share minus the capitalized software asset per share at year-end; and CAPSOFT $i t$ is the net balance of the software asset per share $\left(\mathrm{YR}_{\mathrm{it}}\right.$ are year dummies defined above). If investors value the cumulative amount of capitalized software, we expect $\beta_{3}>0$.

Although equation (2) is frequently used in empirical research (e.g., Collins et al. 1997), it suffers from several shortcomings. While the variables are all per share, and firm size (BVPS) is among the independent variable, it is not clear whether scale (size) is fully controlled for. ${ }^{17}$ Moreover, omitted variables are likely to affect the price regression (2) more than the returns regression (1), since in the latter the omitted variables which are constant over time are eliminated by the differencing operation.

\subsection{CAPITALIZED SOFTWARE AND SUBSEQUENT EARNINGS}

Our third set of value-relevance tests examines the association between capitalization-related variables and future earnings. Because the prediction of future earnings is of considerable importance to investors we interpret a positive association between capitalized software and subsequent earnings as evidence of value-relevance. A positive association is a priori expected, since software capitalization indicates the development program has achieved technological feasibility and the 
capitalized projects have, in management's opinion, positive net present value. (However, if managers systematically abuse their discretion in determining technological feasibility and expected profitability of the developed projects, there should be no relation between capitalization of development costs and subsequent performance). We also test whether the development costs of firms which, as a matter of policy, fully expense them (e.g., Microsoft, Novell), are nevertheless associated with future company performance.

The following cross sectional model is used in the intertemporal test:

$\Delta \mathrm{X}_{\mathrm{it}}^{\mathrm{a}}={ }_{\mathrm{Y}=87}^{95} \beta_{0 \mathrm{Y}} \mathrm{YR}_{\mathrm{it}}+\beta_{1} \Delta \mathrm{X}_{\mathrm{i}, \mathrm{t}-1}^{\mathrm{a}}+\beta_{2} \Delta \mathrm{CAP}_{\mathrm{i}, \mathrm{t}-1}+\beta_{3} \Delta \mathrm{EXP}_{\mathrm{i}, \mathrm{t}-1}+\beta_{4} \Delta \mathrm{EXPCAP}_{\mathrm{i}, \mathrm{t}-1}+\beta_{5} \mathrm{CAPPRE}_{\mathrm{i}, \mathrm{t}-1}+\varepsilon_{\mathrm{it}}$

where: $\Delta^{\mathrm{X}} \mathrm{a}$ is year $\mathrm{t}$ annual change in reported income, either operating or net income, before software development expenses (the software development and amortization expenses were added back to income when appropriate). For firms which did not deduct software development expense from operating income, we of course did not make the adjustment. We estimate expression (3) with one-year ahead $\left(\Delta^{\mathrm{X}} \mathrm{a}\right)$ and two-year ahead $\left(\Delta_{\mathrm{i}, t+1}^{\mathrm{a}}\right)$ earnings changes. (There are thus in total four regressions involving one-and-second-year ahead operating and net income). In (3) $\Delta^{X_{i, t-1}^{a}}$ is the lagged (year t-1) annual change in reported income (either operating or net income), where software development and amortization expenses were added back; $\Delta \mathrm{CAP}_{\mathrm{i}, \mathrm{t}-1}$ is the annual change in capitalized software development costs in year t-1 relative to $\mathrm{t}-2 ; \Delta \mathrm{EXP}_{\mathrm{i}, \mathrm{t}-1}$ is the annual change in software development expense of full expensing firms in year t-1, and 0 for "capitalizers"; $\triangle \mathrm{EXPCAP}_{\mathrm{i}, \mathrm{t}-1}$ is the annual change in the development expense of capitalizing firms in year $\mathrm{t}-1$, and 0 for "expensers"; CAPPRE ${ }_{i, t-1}$ is the predicted value obtained from the regression of software capitalization on the five company attributes described in section 3. We Include CAPPRE $\mathrm{E}_{\mathrm{i}, \mathrm{t}-\mathrm{1}}$ to control for company attributes associated with the capitalization decision. All right-hand variables in 
equation (3) (except CAPPRE $\mathrm{i}_{\mathrm{i}, \mathrm{-}-1}$ and the year indicators $\mathrm{YR}_{\mathrm{it}}$ ) are deflated by beginning of fiscal year t-1 market value.

We expect $\beta_{2}>0$ since projects reaching technological feasibility should increase near-term earnings. We predict $\beta_{4}$ to be smaller than $\beta_{2}$ because investment in projects that have not reached technological feasibility should take, on average, more than a year or two to be reflected in earnings. Moreover, the development cost expensed by capitalizing firms $\left(\triangle \mathrm{EXPCAP}_{\mathrm{it}}\right)$ may also reflect the cost of failed projects which, naturally, will not contribute to future earnings. We have no prediction for $\beta_{3}$, since fully expensing firms provide no information to distinguish between projects before and after technological feasibility, or for the other control variables $\left(\mathrm{YR}_{\mathrm{it}}, \Delta \mathrm{X}_{\mathrm{i}, \mathrm{t}-1}^{\mathrm{a}}\right.$, and CAPPRE $\left.\mathrm{i}_{\mathrm{i}, \mathrm{-}-1}\right)$.

\section{Empirical Findings}

\subsection{CONTEMPOREANOUS ANALYSES}

Table 3 presents estimates of regression (1) for the pooled sample and individual years (1987-1995). In Panel A, the coefficients of the changes in the annual capitalization of development costs and amortization of the software asset ( $\triangle \mathrm{CAP}$ and $\triangle \mathrm{AMRT}$ ) have the expected signs and are highly statistically significant. In addition, as reported in Panel B, the unexpected software capitalization coefficient $(\triangle \mathrm{CAP})$ is positive in all of the nine annual regressions, with $\mathrm{t}$ statistics $>1.65$ in six of nine years. The across-years significance level of $\Delta \mathrm{CAP}$ is 0.01 , as indicated by both Z-statistics ${ }^{18}$. The yearly regressions also indicate that the estimated coefficient of unexpected amortization ( $\triangle \mathrm{AMRT})$ is negative in all years, as expected, with t-statistics $>|1.65|$ in four of nine years (the across-years significance level is 0.01 for Z1 and for Z2). ${ }^{19}$

\section{TABLE 3 HERE}

In contrast with the large and highly significant coefficient of the software capitalization variable $(\triangle \mathrm{CAP})$, the estimated coefficient of fully expensed development costs $(\triangle \mathrm{EXP})$ is only 
0.667 (t-statistic $=1.394)$. In the individual year regressions (bottom panel of Table 3$)$, the coefficient of $\triangle \mathrm{EXP}$ was positive in seven of the nine regressions, and statistically significant $(\mathrm{t}>$

1.65) in three regressions. The low significance level of the unexpected development costs incurred by "expensers" may be partially due to the small number of observations (152) in this subsample, or it may reflect investors' reaction to the absence of information in the financial reports of full expensers on the progress of their development efforts.

The coefficient of the portion of development costs expensed by "capitalizers" ( $\triangle$ EXPCAP) is statistically insignificant in the pooled regression $(t=-0.118)$ as well as in each individual year, perhaps because investors cannot distinguish between the portion of development costs representing research efforts preceding technological feasibility, and the portion representing failed development efforts.

Our yearly regressions allow us to examine directly one of the claims in the Software Publishers Association petition to the FASB - that overtime capitalized software development costs lost their relevance to investors. Inspection of the yearly coefficients of the annually capitalized development cost $(\triangle \mathrm{CAP})$, not reported in Table 3, indicates the contrary: the coefficients of $\triangle \mathrm{CAP}$ were insignificant in the early sample years, 1987-1989, and statistically significant (at the $10 \%$ level) in each of the years, 1990 to 1995 . This suggests that over time the credibility of the amounts of capitalized software development costs increased in capital markets rather than decreased.

We conducted two additional stock return tests. First, we substituted size-adjusted returns for raw returns as the dependent variable in (1), and found the significance levels of the estimates to be somewhat higher than those reported in Table $3 .{ }^{20}$ Second, we added to the sample the 33 firms eliminated because they were acquired or went bankrupt less than three years after going public (see section 2). Estimating regression (1) with those firms yielded very similar results to those reported in Table 3. 
Moving from returns to stock prices, we report in Table 4 estimates from regression (2), which indicate that the coefficient of the balance sheet value of the capitalized software asset (CAPSOFT) is statistically significant and, as predicted, positive. The coefficient, however, is small relative to that of book value (0.57 vs. 2.189). However, when we estimate regression (2) on the 25 percent of the sample cases with the highest capitalization intensity, the coefficient of CAPSOFT is 1.325 (t-value $=8.39)$, substantially higher than that of the total sample $(0.571)$ (results not tabulated). This coefficient (1.325) is still significantly lower (p-value of 0.054$)$ than the estimated coefficient of equity -- 1.771 -- in the regression of the top $25 \%$ capitalizers, indicating that investors discount, on average, the capitalized software asset relative to tangible assets.

\section{TABLE 4 HERE}

Panel B of Table 4 presents estimates of equation (2) from individual year regressions, 1987

to 1995 . The across-years significance level of the software asset (CAPSOFT) is 0.01 , as indicated by both Z-statistics. Furthermore, in all nine years the coefficient of CAPSOFT is positive and in seven years this coefficient is significant at the 0.10 level. The CAPSOFT coefficient is insignificant in 1987 and 1988, perhaps because in those early years of application of SFAS 86 investors were still skeptical about the credibility of software capitalization.

Summarizing, the analyses reported above indicate that both the annual software capitalization amount and the cumulative software asset are positively and significantly associated with stock returns and prices, respectively. ${ }^{21}$ While the software asset reported on the balance sheet appears to be discounted by investors relative to tangible assets, we find no support for the Software Publishers Association's claim that software capitalization data are irrelevant to investors' decisions. In assessing our findings, it should be noted that while over $70 \%$ of sample firms capitalize a portion of their software development costs, the capitalized portion is, on average, rather small, a fact which works against finding significant associations between capitalization-related items and capital market observables.

\subsection{INTERTEMPORAL ANALYSIS}


We augment the contemporaneous capital markets analysis presented above with an intertemporal test of the association between capitalization data and subsequent earnings -- regression (3). ${ }^{22}$ Earnings changes (alternatively, operating and net income) in years $t$ and $t+1$ are regressed on lagged changes in capitalized software, the development costs expensed by "expensers," and the development cost (uncapitalized portion) expensed by "capitalizers." Lagged changes in earnings and the predicted value (CAPPRE) from regressing capitalization intensity on five company attributes (section 3) are included as control variables. We expect that the lagged change in capitalized software $(\triangle \mathrm{CAP})$ will be positively associated with subsequent earnings, and the coefficient of lagged capitalized software $(\triangle \mathrm{CAP})$ will be larger than that of the lagged expensed development costs of full expensers $(\triangle \mathrm{EXP})$ and that of "capitalizers" ( $\triangle \mathrm{EXPCAP})$, since the former reflects products which passed a feasibility test, while the latter two include both early research costs and costs of failed projects.

\section{TABLE 5 HERE}

Regression (3) estimates, presented in Table 5, confirm our expectations. The coefficients of the lagged ( $\mathrm{t}-1)$ change in annual capitalization $(\Delta \mathrm{CAP})$ are positive and highly significant in each of the four regressions (operating and net income, one-year and second-year ahead earnings), indicating that the capitalization change variable is associated with subsequent earnings changes. Furthermore, in each of the four regressions the coefficient of capitalized software ( $\triangle \mathrm{CAP})$ is larger than the coefficient of the development costs expensed by "expensers" $(\Delta \mathrm{EXP})$, which in turn is larger than the coefficient of the development costs expensed by "capitalizers" ( $\mathrm{EXXCAP).}{ }^{23}$ This order of coefficient sizes is consistent with the reasoning of SFAS 86 that capitalized software reflects the costs of projects close to fruition, and should therefore be strongly associated with nearterm earnings, whereas the development costs of "expensers" reflect the costs of both feasible and pre-feasibility projects, which should not be as strongly associated with near-term earnings. The development costs expensed by "capitalizers" reflect both pre-feasibility costs and costs of failed 
projects, consistent with little or no association with subsequent earnings. Note also that the coefficients of the development costs of "expensers" ( $\triangle \mathrm{EXP})$ are statistically significant in the four regressions, while those of "capitalizers" ( $\triangle \mathrm{EXPCAP)}$ are insignificant (except for the bottom regression). This probably reflects the fact that the development expense of full expensers often include cost of projects which passed a feasibility test, despite the fact that those firms chose to fully expense them, while the development expense of "capitalizers" reflects only pre-feasibility or failed projects.

\subsection{QUALITY OF EARNINGS}

It is sometimes argued that capitalization of intangibles adversely affects the quality of reported earnings because it is based on subjective assumptions and is open to manipulation. ${ }^{24}$ If indeed investors perceive earnings under full expensing of software development costs to be of higher quality than earnings under capitalization, that is, if investors adjust the latter for the software capitalization, then the association between adjusted earnings (where the capitalization is reversed) and stock returns should be stronger than that between reported earnings (reflecting capitalization) and stock returns.

We examined this question by regressing annual raw returns on the level and change of

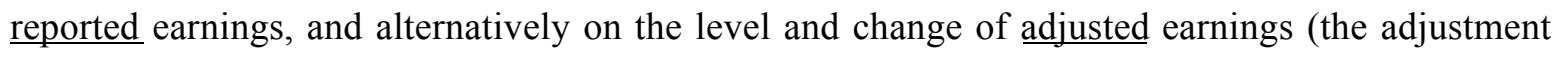
involves subtracting the capitalization of development costs from earnings and adding back to earnings the amortization of the software asset). Both the level and change of earnings are deflated by the beginning of period market value of the firm.

We find that the estimated coefficients of the level and changes of reported earnings $(0.441$ and 0.528$)$ are higher than the coefficients of adjusted earnings $(0.265$ and 0.373$)$, and the $R^{2}$ of the former regression (0.062) is reliably larger (at the 0.08 level) than that of the latter regression (0.036). We thus find no evidence that software capitalization reduces earnings quality. 


\section{Delayed reaction to Expensing?}

Evidence derived from the stock return analysis (Table 3) indicates that investors distinguish between capitalized and expensed software development costs; while unexpected values of the former are positively associated with stock returns, unexpected values of the latter are not. The insignificant coefficient ( $\triangle \mathrm{EXP}$ in table 3 ) of the development costs of firms which, as a matter of policy, fully expense those costs is intriguing, since those firms obviously develop projects which pass feasibility tests. After all, many of the full expensers are successful software developers, and their profitability is, on average, higher than that of firms which capitalize development costs (see Table 2). A possible explanation for the insignificant coefficient of the development costs of full expensers is that, absent disclosures about the progress of projects under development, investors cannot distinguish among costs of projects that passed the feasibility stage, pre-feasibility costs, and costs of failed projects. ${ }^{25}$ Given this uncertainty, investors may discount the development costs of full expensers.

We examine this conjecture by testing for an association between current development costs and future stock returns. Specifically, if the development costs of full expensers are discounted because of investor uncertainty about the progress of the underlying projects, the resolution of this uncertainty as projects reach fruition should induce positive returns. In contrast, the development costs of "capitalizers" which provide information on the success of their production efforts by the act of capitalization, should not be associated with subsequent returns. This test is formalized in (4). $\mathrm{R}_{\mathrm{i}, \mathrm{t}+\mathrm{n}}={ }_{\mathrm{V}=87}^{95} \beta_{0 \mathrm{Y}} \mathrm{YR}_{\mathrm{it}}+\beta_{1} \mathrm{CAP}_{\mathrm{it}}+\beta_{2} \mathrm{EXP}_{\mathrm{it}}+\beta_{3} \mathrm{EXPCAP}_{\mathrm{it}}+\beta_{4} \mathrm{MV}_{\mathrm{it}}+\beta_{5} \mathrm{BETA}_{\mathrm{it}}+\beta_{6} \mathrm{LAGRET}_{\mathrm{it}}+\beta_{7} \mathrm{M} / \mathrm{B}_{\mathrm{it}}+\varepsilon_{\mathrm{it}}$

where: $R_{i, t+n}(n=1,2,3)$ is the firm's annual stock return in the first, second and third year after fiscal $t$ (the return cumulation starts in the fourth month after end of fiscal $t$ ). $\mathrm{CAP}_{i t}$ is the annual software capitalization; $\mathrm{EXP}_{\mathrm{it}}$ is the annual software development expense of "expensers"; and EXPCAP ${ }_{\text {it }}$ is the annual software development expense of "capitalizers". $M V_{i t}$ is the log of market value of firm $i$ three months after end of fiscal year t; BETA $_{i t}$ is the firm's CAPM beta calculated over 100 days 
before fiscal year end; LAGRET $_{\text {it }}$ is the firm's annual stock return cumulated from nine months before fiscal t year-end through three months after it; and $M / B_{i t}$ is the firm's market value three months after end of fiscal year $t$ divided by its book value. The right-hand variables $\mathrm{CAP}_{\mathrm{it}}, \mathrm{EXP}_{\mathrm{it}}$, and EXPCAP ${ }_{i t}$ are scaled by fiscal year $t$ market value. Size $\left(\mathrm{MV}_{\mathrm{it}}\right)$, risk $\left(\mathrm{BETA}_{\mathrm{it}}\right)$, and market-tobook $\left(\mathrm{M} / \mathrm{B}_{\mathrm{it}}\right)$ are risk and performance control variables (e.g., Fama and French 1992). The recent return (LAGRET ${ }_{\text {it }}$ ) accounts for price momentum (Brennan et al. 1997). Controlling for those risk and performance dimensions allows us to focus on the incremental association between software development costs and subsequent returns.

Estimates of (4) are reported in Table 6 for each of the three years following year $t$. Consistent with our conjecture, the development costs of full expensers (EXP), which were not associated with contemporaneous returns (Table 3), are positively and significantly associated with future returns. The size of the coefficient decreases over time as information about products under development is revealed to the market. ${ }^{26}$ The information revelation is relatively quick (2-3 years), commensurate with the typically short production period of software products. The association between full expensers' development costs and subsequent returns is both statistically significant and economically meaningful; on average, first-year and second-year ahead annual returns of $3.17 \%$ and $2.12 \%$, respectively are associated with the fully expensed development costs.

Also, as conjectured, the development costs of "capitalizers" (CAP and EXPCAP) are not generally associated with subsequent returns. The exception is EXPCAP in the first-year ahead regression, but note its small coefficient, 0.389 , relative to that of full expensers, 1.779 . This suggests that capitalization information affects the contemporaneous pricing of securities. Finally, it is unlikely that the different patterns of subsequent returns of capitalizing and expensing companies are due to different risk characteristics, since various risk dimensions are accounted for in expression (4) and all firms belong to the same industry.

If, as suggested by Table 6 evidence, the full expensing of development costs is associated with a delayed investor reaction (underreaction), why don't all software companies capitalize development costs? Two answers are plausible. First, the delayed reaction might not be large enough 
to offset other managerial considerations, such as concern with analysts' claims that capitalization degrades the quality of earnings and the integrity of the balance sheet. Second, managers may not be aware of the uncertainty discount we document. After all, to the best of our knowledge, ours is the first comprehensive evidence consistent with delayed investor reaction to full expensing of software development costs.

\section{Why the Petition to Abolish SFAS 86?}

Our analysis indicates that data on capitalized software development costs summarize information relevant to investors. What then prompted the 1996 Software Publishers Association (SPA) petition to abolish SFAS 86? This question is particularly intriguing, given the considerable implementation flexibility afforded by this standard.

An analysis of the reporting consequences of intangibles' capitalization vs. expensing (e.g., Beaver and Ryan 1997) suggests that early in the life of a firm or an industry, when the growth of intangible investment generally exceeds the firm's return on equity, capitalization enhances reported income proportionately more than equity, implying a higher reported return on equity (ROE) or return on assets (ROA) under capitalization than under full expensing. As the firm matures, its profitability generally increases while the rate of intangible investment declines; the enhancing effect of capitalization on income diminishes, while the cumulative effect of capitalization on equity or total assets increases, resulting in a higher ROE and ROA under expensing than under capitalization. The inflection point lies close to the point where the growth rate of intangible investment equals the firm's ROE under expensing. From that point on, ROE (ROA) based on immediate expensing of intangible investments will be larger than ROE (ROA) based on capitalization. Similar reasoning applies to the level of reported earnings: early on, capitalization enhances reported earnings, whereas during the mature phase of operations, the increasing amortization charges of the capitalized asset largely offset the income-enhancing effect of capitalization, rendering software capitalization less attractive than full expensing in terms of maximizing reported earnings. Thus, the difference between earnings under capitalization and expensing changes over the life cycle of the firm. 
Many software companies have experienced a decreasing growth rate of software development costs, and the consequent diminishing appeal of capitalization. Sample firms with eight years of data had in 1989 an average annual growth rate of software development costs (deflated by total assets) of $16.8 \%$, declining to $5.6 \%$ in 1995 . Obviously, capitalization of development costs in the mid-1990s was less attractive to these firms in terms of reported earnings than it was a decade earlier, providing incentives to lobby for the abolition of SFAS 86.

To examine our conjecture about the diminished appeal of software capitalization in the 1990s, we computed for each sample firm and year the impact of development cost capitalization on reported earnings (i.e., annually capitalized amount divided by operating earnings before software development expense), and the impact of amortization of the software asset on reported earnings (i.e., annual amortization divided by operating earnings before software development expense). The former (capitalization) factor increases reported earnings while the latter (amortization) factor decreases earnings. Figure 1 presents the median yearly impacts of capitalization and amortization on operating earnings of the sample firms.

It is clear from Figure 1 that up to 1992, the application of SFAS 86 substantially enhanced reported earnings. In 1993 and 1994 the gap between the income-enhancing effect of capitalization and the detracting effect of amortization diminished substantially, and vanished in 1995 . Thus, since 1993, software capitalization became progressively less attractive in terms of reported earnings. ${ }^{27}$ Similar inferences are drawn from an analysis of sample firms’ ROE (not reported).

\section{FIGURE 1 HERE}

Our analysis, which is based on individual firms, does not explain why the industry petitioned the FASB for abolition of SFAS 86, rather than individual firms ceasing to capitalize development costs when capitalization no longer served their purposes. We conjecture that abolition of the standard is preferred over individual changes of accounting practice, since the latter may be interpreted as an indication that the company's development process faltered. Specifically, abandoning capitalization may signal that projects under development failed to reach technological 
feasibility required by SFAS 86 for capitalization (see appendix). In contrast, when all firms stop capitalizing because of a change in accounting standard, such negative inferences are avoided. ${ }^{28}$

\section{Analysts' Motives}

Analysts' skepticism toward the capitalization of software development costs is even more intriguing than managers' ${ }^{29}$ A priori, capitalization allows managers to inform investors about the progress and success of the software development program. In the worst case, if concerns about manipulation are overwhelming, software capitalization can be easily undone by subtracting the periodic capitalized amount from earnings. Of course, if well connected analysts obtain private operating information on products under development, their success rate and expected market share, then analysts' objection to the public disclosure of such information (partially provided via the capitalization and amortization of software development costs) is understandable.

This self-serving motive, is very difficult to substantiate empirically. We therefore focus on another, perhaps equally compelling explanation for analysts' opposition to capitalization, which is related to the effect of software capitalization on the accuracy of analysts' earnings forecasts. Software development costs typically account for $20-30 \%$ of revenues; capitalization of an unknown portion of such a large cost component increases the difficulty of predicting the development expense (total development cost minus capitalization) and consequently predicting earnings, since the amount capitalized each period is determined by the largely unpredictable success rate and profit potential of the products under development. Analysts concerned with the size of their earnings forecast errors can therefore be expected to view capitalization negatively. ${ }^{30}$

To examine this conjecture, we computed analysts' relative earnings forecast errors for the sample firms (reported annual earnings per share minus Zacks analysts' forecasts, divided by stock price at year end). We expect a positive association between the absolute size of analysts' forecast errors and the extent of software capitalization. ${ }^{31}$ We measure the extent of software capitalization by the annual amount capitalized, scaled by beginning-of-year market value (CAP in expression (5)). ${ }^{32}$ We also control for factors related to forecast accuracy: the age (horizon) of the forecast; 
the number of analysts following the firm; and firm size. ${ }^{33}$ Expression (5) presents our regression model:

$$
\mathrm{FE}_{\mathrm{it}}={ }_{\mathrm{Y}=87}^{95} \beta_{0 \mathrm{Y}} \mathrm{YR}_{\mathrm{it}}+\beta_{1} \mathrm{CAP}_{\mathrm{it}}+\beta_{2} \mathrm{NUMANA}_{\mathrm{it}}+\beta_{3} \mathrm{AGE}_{\mathrm{it}}+\beta_{4} \mathrm{MV}_{\mathrm{it}}+\varepsilon_{\mathrm{it}}
$$

where: $\mathrm{FE}_{\mathrm{it}}$ is, alternatively, absolute value of individual analysts' relative forecast errors, firmspecific average forecast error, and the firm's standard deviation of the forecast error. The forecast error is measured as the absolute value of reported annual EPS minus the forecast, scaled by end-ofyear stock price. $\mathrm{YR}_{\mathrm{it}}$ are year dummies; $\mathrm{CAP}_{\mathrm{it}}$ is the annual amount of software development cost which was capitalized by the firm, scaled by beginning-of-year market value; NUMANA $_{i t}$ is the number of analysts following the firm; $\mathrm{AGE}_{\mathrm{it}}$ is the interval (in days) between the forecast date and the earnings announcement date; and $\mathrm{MV}_{\mathrm{it}}$ is the $\log$ of the firm's market value of equity at year-end.

\section{TABLE 7 HERE}

Table 7 presents estimates from the three regression versions of (5). In a regression of absolute value of individual forecast errors on capitalization intensity and market value, CAP is positively associated with the absolute size of forecast errors, and size (MV) is negatively related to the forecast error. The second regression in Table 7 reports firm-specific absolute mean forecast errors regressed on capitalization intensity and all three control variables. Capitalized development costs (CAP) are positively associated with analysts' mean forecast error. Forecast age and firm size are significantly associated with the mean forecast error in the expected direction. Finally, in the third regression, capitalization intensity is also significantly and positively associated with the firmspecific standard deviation of analysts forecasts.

Our findings are thus consistent with the conjecture that analysts' objection to software capitalization may be related to the adverse effect of capitalization on the quality of their earnings forecasts. This conclusion seems to run counter to our previous conclusion (Section 5.2) that capitalization improves the prediction of earnings. In fact, these findings are not inconsistent since the findings in section 5.2 (and Table 5) are for earnings before the software expense. The analyst 
forecast results relate to reported earnings after the expensing of software development costs, and indicate that capitalization introduces noise to these earnings.

\section{Concluding Remarks}

We examine both the 10-year record of SFAS 86, the major exception in the US to the immediate expensing of R\&D, and the validity of arguments advanced in the March 1996 petition of the Software Publishers Association (SPA) to abolish SFAS 86. Our contemporaneous (stock prices and returns) as well as intertemporal (subsequent earnings) analyses indicate that capitalizationrelated variables (annual amount capitalized, the value of the software asset and its amortization) are significantly associated with capital market variables and future earnings. We conclude that software capitalization summarizes information relevant to investors. In generalizing our findings to the capitalization of intangibles, such as $\mathrm{R} \& \mathrm{D}$, it should be recalled that software capitalization reflects only the post-feasibility portion of the development cost component of R\&D.

Regarding the motives underlying the SPA petition, we provide evidence that during the 1990s the appeal of software capitalization in terms of enhancing reported earnings continually diminished. As to financial analysts' skepticism about capitalization, we provide evidence that software capitalization is associated with larger errors in analysts' forecasts of earnings, due to the random element introduced to earnings by capitalization. This adverse effect of capitalization on the quality of forecasts may help explain the objection of some analysts to software capitalization in particular, and to the capitalization of intangible investments (e.g., R\&D) in general. 


\section{REFERENCES}

American Institute of Certified Public Accountants. Statement of Position 98-1, Accounting for the Costs of Computer Software Developed or Obtained for Internal Use. New York: AICPA, 1998.

Altman, E. "Financial ratios, discriminant analysis, and the prediction of corporate bankruptcy." Journal

of Finance (1968): 587-609.

Association for Investment Management and Research. Financial Reporting in the 1990s and Beyond.

Charlottesville, VA: AIMR, 1993.

Barth, M. and S. Kallapur. "The effects of cross-sectional scale differences on regression results in empirical accounting research.” Contemporary Accounting research (1996): 527-567.

Beaver, W. and S. Ryan. "Biased (conservative) and delayed accounting recognition and their effects on

the ability of the book-to-market ratio to predict book return on equity." Working paper, New York

University, 1997.

Biddle, G., G. Seow and A. Siegel. "Relative versus incremental information content."

Contemporary Accounting Research (1995): 1-23.

Brennan, M., T. Chordia and A. Subrahmanyam. "Alternative factor specifications, security characteristics, and the cross-section of expected returns." Forthcoming, Journal of Financial Economics (1997).

Collins, D., E. Maydew, and I, Weiss. "Changes in the value-relevance of earnings and book values over the past forty years." Journal of Accounting and Economics (1997): 39-68.

Deloitte \& Touche LLP, 1996, Research and Development Survey of Software Companies. Deng, Z. and B. Lev. "The valuation of acquired R\&D-in-process.” Working paper, New York University, 1998. 
Easton, P. and T. Harris. "Earnings as an explanatory variable for returns" Journal of Accounting Research (1991): 19-36. , and J. Ohlson. "Accounting earnings can explain most of security returns: the case of long event windows." Journal of Accounting and Economics (1992): 119-142.

Eccher, E. "The value relevance of software capitalized costs." Working paper, Northwestern University, 1995

Fama, E., and K. French. "The cross-section of expected returns." Journal of Finance (1992): 427-465.

Financial Accounting Standards Board. SFAS No. 2, Accounting for Research and Development Costs. Stamford Conn.: FASB, 1974.

Financial Accounting Standards Board. SFAS No. 86, Accounting for the Costs of Computer Software to be Sold, Leased, or Otherwise Marketed. Stamford Conn.: FASB, 1985.

Financial Accounting Standards Board. Public record: position papers submitted in respect of exposure

Draft -- Accounting for the Costs of Computer Software to be Sold, Leased, or Otherwise Marketed. Volumes I and II. Stamford Conn.: FASB, 1985.

Francis, J., and K. Schipper. "Have financial statements lost their relevance?" Working paper, University of Chicago, 1996.

Gort, M. and S. Klepper. "Time paths in the diffusion of product innovation." Economic Journal (1982): 630-653.

Hall, B. "The private and social returns to R\&D: what have we learned?" Working paper, UC Berkeley, 1995. Internatioal Accounting Standards Committee. Standard no. 38, Intangible Assets, ISAC, 1998. Jarnagin, B. Financial Accounting Standards. Chicago, IL.: Commerce Clearing House, Inc., 1993. Klepper, S. and E. Graddy. "The evolution of new industries and the determinants of market structure." 
Rand Journal of Economics (1990): 27-44.

Lev, B. and T. Sougiannis. "The capitalization, amortization, and value-relevance of R\&D." Journal of Accounting and Economics (1996): 107-138.

Mikhail, M., B. Walther, and R. Willis. "Do security analysts improve their performance with experience?" Journal of Accounting Research (1997): 131-157.

Ohlson, J. "Earnings, Book Values and Dividends In Security Valuation.” Contemporary Accounting Research (1997): 661-687. , and P. Shroff. "Changes versus levels in earnings as explanatory variables for returns: some theoretical considerations." Journal of Accounting Research (1992): 210-226.

Trombley, M. "Accounting method choice in the software industry: characteristics of firms electing early adoption of SFAS No. 86." The Accounting Review (1992): 529-538.

Vuong, Q. "Likelihood ratio test for model selection and non-nested hypotheses." Econometrica, (1989): 307-333.

White, H. "A heteroskedasticity-consistent covariance matrix-estimator and a direct Test for Heteroskedasticity." Econometrica (1989): 817-838. Asymptotic theory for econometricians. Orlando FL, Academic press, 1984. 


\section{TABLE 1}

Sample Summary Statistics

Means and Medians of Various Attributes of the 163 Sample Companies During 1987-1995

\begin{tabular}{|c|c|c|c|c|c|c|c|c|c|c|c|c|c|}
\hline \multirow[b]{2}{*}{ Year } & \multirow[b]{2}{*}{$\mathrm{N}$} & \multicolumn{2}{|c|}{$\begin{array}{l}\text { Sales } \\
\text { (\$ million) } \\
\end{array}$} & \multicolumn{2}{|c|}{$\begin{array}{l}\text { Total Assets } \\
\text { (\$ million) }\end{array}$} & \multicolumn{2}{|c|}{$\mathrm{ROE}^{1}$} & \multicolumn{2}{|c|}{ Market/Book } & \multicolumn{2}{|c|}{$\begin{array}{c}\text { Long-term } \\
\text { Debt / Equity } \\
\end{array}$} & \multicolumn{2}{|c|}{$\begin{array}{c}\text { Capitalization } \\
\text { Intensity }^{3}\end{array}$} \\
\hline & & Median & Mean & Median & Mean & Median & Mean & Median & Mean & Median & Mean & Median & Mean \\
\hline 1987 & 58 & 24.96 & 70.41 & 32.58 & 69.61 & 0.20 & 0.13 & 2.31 & 3.69 & 0.04 & 0.15 & 0.29 & 0.35 \\
\hline 1988 & 68 & 35.96 & 86.30 & 33.94 & 82.32 & 0.10 & 0.09 & 2.63 & 4.83 & 0.04 & 0.21 & 0.26 & 0.31 \\
\hline 1989 & 78 & 33.83 & 102.98 & 36.28 & 98.36 & 0.17 & 0.07 & 2.89 & 4.47 & 0.03 & 0.15 & 0.25 & 0.31 \\
\hline 1990 & 81 & 39.36 & 123.28 & 37.72 & 117.03 & 0.17 & 0.08 & 2.86 & 4.30 & 0.01 & 0.15 & 0.21 & 0.30 \\
\hline 1991 & 96 & 41.53 & 129.29 & 40.58 & 126.40 & 0.13 & -0.07 & 3.77 & 5.44 & 0.01 & 0.13 & 0.25 & 0.32 \\
\hline 1992 & 106 & 45.53 & 151.37 & 44.10 & 147.99 & 0.13 & 0.01 & 4.34 & 5.67 & 0.01 & 0.20 & 0.26 & 0.30 \\
\hline 1993 & 129 & 40.02 & 155.64 & 43.92 & 155.49 & 0.08 & -0.15 & 3.88 & 5.06 & 0.01 & 0.19 & 0.17 & 0.25 \\
\hline 1994 & 130 & 51.35 & 204.97 & 49.63 & 207.65 & 0.15 & 0.08 & 3.96 & 5.86 & 0.00 & 0.19 & 0.12 & 0.20 \\
\hline 1995 & 116 & 50.94 & 265.23 & 56.39 & 283.66 & 0.11 & -0.03 & 4.64 & 6.83 & 0.00 & 0.08 & 0.08 & 0.17 \\
\hline
\end{tabular}

${ }^{1}$ Reported net income over beginning-of-year equity.

${ }^{2}$ Both debt and equity are measured at book values.

${ }^{3}$ Annual capitalized software development costs divided by total development costs (i.e., the development expense plus the capitalized portion). 


\section{TABLE 2}

Firm Attributes Associated With Capitalization Intensity

Regression Analysis For 778 firm- years from 1987-1995

$$
\mathrm{CAPVAL}_{\mathrm{it}}={ }_{\mathrm{Y}=87}^{95} \beta_{0 \mathrm{Y}} \mathrm{YR}_{\mathrm{it}}+\beta_{1} \mathrm{MV}_{\mathrm{it}}+\beta_{2} \mathrm{X}_{\mathrm{it}}+\beta_{3} \text { Devint }_{\mathrm{it}}+\beta_{4} \text { Leverage }_{\mathrm{it}}+\beta_{5} \mathrm{Beta}_{\mathrm{it}}+\varepsilon_{\mathrm{it}}
$$

\begin{tabular}{lcc}
\hline \hline Independent Variable & Coefficient Estimate & t-statistic \\
\hline MV (size) & -0.007 & -4.397 \\
X (profitability) & -0.040 & -4.286 \\
Devint (development intensity) & 0.269 & 6.024 \\
Leverage & 0.001 & 1.848 \\
Beta (systematic risk) & 0.006 & 1.506 \\
Adjusted R & & 0.148 \\
\end{tabular}

Variable definition: CAPVAL is the annually capitalized development cost divided by yearend market value (0 for "expensers"). MV (size) is the log of market value of equity three months after fiscal year-end. $\mathrm{X}$ (profitability) is net income plus the annual software amortization minus the annual capitalized software (that is, earnings under full expensing), divided by sales. Devint (development intensity) is the annual software development costs (capitalized software development plus software development expense) divided by sales. Leverage is the long-term debt divided by equity (minus the software asset), and beta (systematic risk) is the CAPM $\beta$ of the stock, estimated over 100 days prior to fiscal year end. 
TABLE 3

The Value-Relevance of Software Capitalization

Regression Estimates of Annual Stock Returns on Reported

Financial Data and Capitalization-Related Items (t-values in Parentheses).

\section{Panel A: Pooled Sample (1987-1995)}

Model: $\quad \mathrm{R}_{\mathrm{it}}={ }_{\mathrm{Y}=87}^{95} \beta_{0 \mathrm{Y}} \mathrm{YR}_{\mathrm{it}}+\beta_{1} \Delta \mathrm{CAP}_{\mathrm{it}}+\beta_{2} \Delta \mathrm{EXP}_{\mathrm{it}}+\beta_{3} \Delta \mathrm{EXPCAP}_{\mathrm{it}}+\beta_{4} \Delta \mathrm{AMRT}_{\mathrm{it}}+\beta_{5} \mathrm{X}_{\mathrm{it}}^{\mathrm{a}}+\beta_{6} \Delta \mathrm{X}_{\mathrm{it}}^{\mathrm{a}}+\beta_{7} \mathrm{CAPPRE}_{\mathrm{it}}+\varepsilon_{\mathrm{it}}$

\begin{tabular}{|c|c|c|c|c|c|c|c|c|}
\hline Dependent Variable & $\Delta \mathrm{CAP}_{\mathrm{it}}$ & $\Delta \mathrm{EXP}_{\text {it }}$ & $\Delta \mathrm{EXPCAP}_{\mathrm{it}}$ & $\Delta \mathrm{AMRT}_{\mathrm{it}}$ & $\mathrm{X}_{\mathrm{it}}^{\mathrm{a}}$ & $\Delta X_{i t}^{a}$ & CAPPRE $_{\text {it }}$ & Adjusted R $^{2}$ \\
\hline Raw return & $\begin{array}{c}1.488 \\
(6.637)\end{array}$ & $\begin{array}{c}0.667 \\
(1.394)\end{array}$ & $\begin{array}{c}-0.089 \\
(-0.118)\end{array}$ & $\begin{array}{c}-2.207 \\
(-2.908)\end{array}$ & $\begin{array}{c}1.170 \\
(9.583)\end{array}$ & $\begin{array}{c}0.368 \\
(2.905)\end{array}$ & $\begin{array}{c}-0.912 \\
(-2.220)\end{array}$ & 0.241 \\
\hline \multicolumn{9}{|c|}{ Panel B: Nine Separate Year Regressions (1987-1995) } \\
\hline Mean coefficient & 1.71 & 0.99 & -0.35 & -2.59 & 1.43 & 2.11 & -1.76 & \\
\hline Number of coefficients $>0$ & 9 & 7 & 6 & 0 & 9 & 8 & 2 & \\
\hline $\mathrm{Z2}$ & 6.27 & 1.43 & 0.38 & -4.45 & 9.71 & 5.86 & -4.30 & \\
\hline
\end{tabular}

Regression results are based on 711 firm years (4 firm years identified as outliers were removed). Panel A regression includes year intercept dummies (not reported). Reported t-statistics are based on White [1980] standard errors.

$\mathrm{R}_{\mathrm{it}}$ is the firm's annual stock return, cumulated from nine months before fiscal t year-end through three months after it, $\Delta C A P_{i t}$ is the annual change in software capitalization, $\Delta \mathrm{EXP}_{\mathrm{it}}$ is the annual change in software development expense for firms classified as "expensers",

$\triangle$ EXPCAP $_{\text {it }}$ is the annual change in software development expense for firms classified as "capitalizers", $\Delta \mathrm{AMRT}_{\text {it }}$ is the annual change in amortization of the software asset, $X_{i t}^{a}$ is the adjusted net income of firm $i$ in year $t$ (i.e., reported annual net income plus the software development expense and amortization of the software asset), $\Delta \mathrm{X}_{\mathrm{it}}^{\mathrm{a}}$ is the annual change in income, CAPPRE $\mathrm{E}_{\mathrm{it}}$ is a predicted value obtained from regressing capitalization intensity on five company attributes (see Table 2). All right-hand variables (except the year intercept dummies and $\mathrm{CAPPRE}_{\mathrm{it}}$ ) are scaled by beginning of fiscal year market value.

$\mathrm{Z}_{1}=(1 / \sqrt{\mathrm{T}}) \quad \mathrm{j}_{\mathrm{j}=1}\left(\mathrm{t}_{\mathrm{j}} / \sqrt{\mathrm{K}_{\mathrm{j}} /\left(\mathrm{k}_{\mathrm{j}}-2\right)}\right)$ where $\mathrm{t}_{\mathrm{j}}$ is $\mathrm{t}$-statistic for year $\mathrm{j}, \mathrm{k}_{\mathrm{j}}$ is degrees of freedom, and $\mathrm{T}$ is number of years.

$\mathrm{Z}_{2}=$ mean $\mathrm{t}$-statistic $/($ standard deviation of t-statistics $/ \sqrt{\mathrm{T}-1})$. 
TABLE 4

The Value-Relevance of Software Asset

Regression Estimates of Stock Price on Reported Financial

Data and Capitalization-Related Items ( $t$-values in Parentheses).

\begin{tabular}{|c|c|c|c|c|}
\hline \multicolumn{5}{|c|}{$\begin{array}{l}\text { Panel A: Pooled Sample (1987-1995) } \\
\text { Model: } P_{i t}={ }_{Y=87}^{95} \beta_{0 Y} Y_{i t}+\beta_{1} E S_{i t}+\beta_{2} B_{P P S} S_{i t}^{a}+\beta_{3} C_{A P S O F T}+\varepsilon_{i t}\end{array}$} \\
\hline & EPS & BVPS $^{\text {a }}$ & CAPSOFT & Adjusted $\mathrm{R}^{2}$ \\
\hline $\begin{array}{l}\text { Dependent Variable } \\
\text { Stock Price }\end{array}$ & $\begin{array}{l}3.509 \\
(10.97)\end{array}$ & $\begin{array}{l}2.189 \\
(19.37)\end{array}$ & $\begin{array}{l}0.57 \\
(2.06)\end{array}$ & 0.57 \\
\hline
\end{tabular}

Panel B: Nine Separate Year Regressions (1987-1995)

\begin{tabular}{|c|c|c|c|}
\hline & EPS & $\mathrm{BVPS}^{\mathrm{a}}$ & CAPSOFT \\
\hline Mean coefficient & 4.489 & 2.031 & 1.418 \\
\hline Number of coefficients $>0$ & 9 & 9 & 9 \\
\hline Number of t-statistic $>1.65$ & 9 & 9 & 7 \\
\hline $\mathrm{Z} 1$ & 12.70 & 18.97 & 4.86 \\
\hline $\mathrm{Z2}$ & 8.35 & 6.45 & 3.64 \\
\hline
\end{tabular}

Regression results are based on 862 firm years ( 3 firm years identified as outliers were removed). The regression in panel A includes year intercept dummies (not reported). Reported t-statistics are based on White [1980] standard errors.

$\mathrm{P}_{\mathrm{it}}$ is the stock price three months after fiscal year-end, BVPS $\mathrm{it}$ is the fiscal year-end adjusted book value per share, namely the book value of equity minus the net balance of the capitalized software asset, CAPSOFT $i \mathrm{it}$ is the fiscal year-end balance per share of the software asset, net of the accumulated amortization.

$\mathrm{Z}_{1}=(1 / \sqrt{\mathrm{T}}){ }_{\mathrm{j}=1}^{\mathrm{L}}\left(\mathrm{t}_{\mathrm{j}} / \sqrt{\mathrm{K}_{\mathrm{j}} /\left(\mathrm{k}_{\mathrm{j}}-2\right)}\right)$ where $\mathrm{t}_{\mathrm{j}}$ is $\mathrm{t}$-statistic for year $\mathrm{j}, \mathrm{k}_{\mathrm{j}}$ is degrees of freedom, and $\mathrm{T}$ is number of years.

$\mathrm{Z}_{2}=$ mean $\mathrm{t}$-statistic $/$ (standard deviation of t-statistics $\left./ \sqrt{\mathrm{T}-1}\right)$. 


\section{TABLE 5}

Software Capitalization and Subsequent Earnings

Regression of Earnings (Operating and Net Income) in Years $t$ and $t+1$ on Capitalization Related Variables in $t-1$ (t-values in Parentheses).

Models: $\Delta \mathrm{OI}_{\mathrm{it}}={ }_{\mathrm{Y}=87}^{94} \beta_{0 \mathrm{Y}} \mathrm{YR}_{\mathrm{it}}+\beta_{1} \Delta \mathrm{OI}_{\mathrm{i}, \mathrm{t}-1}+\beta_{2} \Delta \mathrm{CAP}_{\mathrm{i}, \mathrm{t}-1}+\beta_{3} \Delta \mathrm{EXP}_{\mathrm{i}, \mathrm{t}-1}+\beta_{4} \Delta \mathrm{EXPCAP}_{\mathrm{i}, \mathrm{t}-1}+\beta_{5} \mathrm{CAPPRE}_{\mathrm{i}, \mathrm{t}-1}+\varepsilon_{\mathrm{i}}$

$\Delta \mathrm{NI}_{\mathrm{it}}={ }^{94} \beta_{0 \mathrm{Y}} \mathrm{YR}_{\mathrm{it}}+\beta_{1} \Delta \mathrm{NI}_{\mathrm{i}, \mathrm{t}-1}+\beta_{2} \Delta \mathrm{CAP}_{\mathrm{i}, \mathrm{t}-1}+\beta_{3} \Delta \mathrm{EXP}_{\mathrm{i}, \mathrm{t}-1}+\beta_{4} \Delta \mathrm{EXPCAP}_{\mathrm{i}, \mathrm{t}-1}+\beta_{5} \mathrm{CAPPRE}_{\mathrm{i}, \mathrm{t}-1}+\varepsilon_{\mathrm{i}}$

\begin{tabular}{|c|c|c|c|c|c|c|}
\hline Dependent Variable & $\Delta \mathrm{NI}_{\mathrm{i}, \mathrm{t}-1}\left(\Delta \mathrm{OI}_{\mathrm{I}, \mathrm{t}-1}\right)$ & $\Delta \mathrm{CAP}_{\mathrm{i}, \mathrm{t}-1}$ & $\Delta \mathrm{EXP}_{\mathrm{i}, \mathrm{t}-1}$ & $\Delta \mathrm{EXPCAP}_{\mathrm{i}, \mathrm{t}-1}$ & CAPPREi $_{i, t-1}$ & $\overline{\text { Adjusted } \mathrm{R}}$ \\
\hline \multicolumn{7}{|l|}{ One-year ahead: } \\
\hline$\Delta \mathrm{OI}_{\mathrm{t}}$ & $\begin{array}{l}-0.075 \\
(-2.75)\end{array}$ & $\begin{array}{c}0.309 \\
(3.696)\end{array}$ & $\begin{array}{c}0.256 \\
(3.627)\end{array}$ & $\begin{array}{c}0.095 \\
(0.643)\end{array}$ & $\begin{array}{c}0.082 \\
(1.030)\end{array}$ & 0.146 \\
\hline$\Delta \mathrm{NI}_{\mathrm{t}}$ & $\begin{array}{c}0.140 \\
(5.125)\end{array}$ & $\begin{array}{c}0.291 \\
(9.972)\end{array}$ & $\begin{array}{c}0.128 \\
(1.699)\end{array}$ & $\begin{array}{c}-0.028 \\
(-0.223)\end{array}$ & $\begin{array}{c}0.008 \\
(0.101)\end{array}$ & 0.238 \\
\hline$\frac{\text { Second-year ahead: }}{\Delta \mathrm{OI}_{\mathrm{t}+1}}$ & $\begin{array}{c}0.040 \\
(2.886)\end{array}$ & $\begin{array}{c}1.432 \\
(11.185)\end{array}$ & $\begin{array}{c}0.189 \\
(1.428)\end{array}$ & $\begin{array}{c}0.052 \\
(1.168)\end{array}$ & $\begin{array}{l}-0.400 \\
(-3.922)\end{array}$ & 0.333 \\
\hline$\Delta \mathrm{NI}_{\mathrm{t}+1}$ & $\begin{array}{c}0.098 \\
(9.481)\end{array}$ & $\begin{array}{c}1.013 \\
(5.461)\end{array}$ & $\begin{array}{c}0.366 \\
(1.998)\end{array}$ & $\begin{array}{c}0.260 \\
(5.961)\end{array}$ & $\begin{array}{c}0.103 \\
(0.961)\end{array}$ & 0.271 \\
\hline
\end{tabular}

One-year ahead egression results are based on 511 firm years (1987-1994). Second-year ahead $\mathrm{t}+1$ regression results are based on 402 firm years (1987-1993). The regressions include year intercept dummies (not reported). Reported t-statistics are based on White [1980] standard errors.

The dependent variables are: $\Delta \mathrm{OI}_{\mathrm{it}}$ is the change in operating income in year $\mathrm{t}$ where development and amortization expenses are added back, and $\Delta \mathrm{NI}_{\mathrm{it}}$ is the change in net income in year $\mathrm{t}$ where development and amortization expenses are added back. $\Delta \mathrm{OI}_{\mathrm{i}, \mathrm{t}+1}$ is the change in operating income in year $\mathrm{t}+1$ where development and amortization expenses are added back, and $\Delta \mathrm{NI}_{\mathrm{i}, \mathrm{t}+1}$ is the change in net income in year $\mathrm{t}+1$ where development and amortization expenses are added back. The independent variables are: $\Delta \mathrm{OI}_{\mathrm{i}, \mathrm{t}-1}$ and $\Delta \mathrm{NI}_{\mathrm{i}, \mathrm{t}-1}$ are the lagged (year $\mathrm{t}-$ 1) annual change in $\mathrm{OI}$ and NI, respectively, $\Delta \mathrm{CAP}_{\mathrm{i}, \mathrm{t}-\mathrm{1}}$ is the annual change in the amount of capitalized software development costs in year $\mathrm{t}-1, \Delta \mathrm{EXP}_{\mathrm{i}, \mathrm{t}-1}$ is the annual change in the development expense for full expensing firms in year $\mathrm{t}-1$ and 0 for "capitalizers", $\Delta \mathrm{EXPCAP}_{\mathrm{i}, \mathrm{t}-1}$ is the annual change in the development expense for capitalizing firms in year $\mathrm{t}-1$ and 0 for "expensers", $\mathrm{CAPPRE}_{\mathrm{i}, \mathrm{t}-1}$ is the predicted value 
from a first stage regression defined in Table 2. All left-hand and right-hand variables (except $\mathrm{CAPPRE}_{\mathrm{it}}$ and $\mathrm{YR}_{\mathrm{it}}$ ) are deflated by beginning of respective fiscal year market value.

\section{Table 6}

Software Capitalization and Subsequent Stock Returns

Regression Estimates of Annual Future Stock Returns on Software Development Costs and Control variables ( $t$-values in Parentheses).

Model: $\mathrm{R}_{\mathrm{it}+\mathrm{n}}={ }_{\mathrm{Y}=87}^{95} \beta_{0 \mathrm{Y}} \mathrm{YR}_{\mathrm{it}}+\beta_{1} \mathrm{CAP}_{\mathrm{it}}+\beta_{2} \mathrm{EXP}_{\mathrm{it}}+\beta_{3} \mathrm{EXPCAP}_{\mathrm{it}}+\beta_{4} \mathrm{MV}_{\mathrm{it}}+\beta_{5} \mathrm{BETA}_{\mathrm{it}}+\beta_{6} \mathrm{LAGRET}_{\mathrm{it}}+\beta_{7} \mathrm{M} / \mathrm{B}_{\mathrm{it}}+\varepsilon_{\mathrm{it}}$

\begin{tabular}{|c|c|c|c|c|c|c|c|c|}
\hline Dependent Variable & $\mathrm{CAP}_{\mathrm{it}}$ & $\mathrm{EXP}_{\mathrm{it}}$ & EXPCAP $_{\text {it }}$ & $\mathrm{MV}_{\text {it }}$ & BETA $_{\text {it }}$ & LAGRET $_{\text {it }}$ & $\mathrm{M} / \mathrm{B}_{\mathrm{it}}$ & Adjusted R \\
\hline Raw return $(\mathrm{t}+1)$ & $\begin{array}{c}0.035 \\
(0.089)\end{array}$ & $\begin{array}{c}1.779 \\
(4.825)\end{array}$ & $\begin{array}{c}0.389 \\
(2.126)\end{array}$ & $\begin{array}{c}0.063 \\
(4.076)\end{array}$ & $\begin{array}{c}0.030 \\
(0.924)\end{array}$ & $\begin{array}{c}-0.025 \\
(-0.837)\end{array}$ & $\begin{array}{c}-0.007 \\
(-2.417)\end{array}$ & 0.124 \\
\hline Raw return $(t+2)$ & $\begin{array}{c}0.031 \\
(0.079)\end{array}$ & $\begin{array}{c}1.166 \\
(2.942)\end{array}$ & $\begin{array}{c}0.051 \\
(0.224)\end{array}$ & $\begin{array}{c}0.068 \\
(3.868)\end{array}$ & $\begin{array}{c}-0.049 \\
(-1.126)\end{array}$ & $\begin{array}{c}-0.036 \\
(-1.097)\end{array}$ & $\begin{array}{c}-0.011 \\
(-2.318)\end{array}$ & 0.136 \\
\hline Raw return $(\mathrm{t}+3)$ & $\begin{array}{c}-0.160 \\
(-0.391)\end{array}$ & $\begin{array}{c}0.390 \\
(0.957)\end{array}$ & $\begin{array}{c}-0.325 \\
(-1.384)\end{array}$ & $\begin{array}{c}0.071 \\
(3.571)\end{array}$ & $\begin{array}{c}-0.098 \\
(-1.861)\end{array}$ & $\begin{array}{c}0.001 \\
(0.022)\end{array}$ & $\begin{array}{c}-0.022 \\
(-3.335)\end{array}$ & 0.180 \\
\hline
\end{tabular}

Regression results for one-year, second-year, and third-year ahead raw returns are based on 559, 426 and 318 firm years respectively (6 firm-years identified as outliers were removed). The regressions include year intercept dummies (not reported). Reported t-statistics are based on White [1980] standard errors.

$\mathrm{R}_{\mathrm{it}}$ is the firm's future annual stock return in years $\mathrm{t}+1, \mathrm{t}+2$, and $\mathrm{t}+3$. CAP $\mathrm{P}_{\text {it }}$ is the annual software capitalization, $\mathrm{EXP}_{\text {it }}$ is the annual software development expense for firms classified as "expensers", EXPCAP ${ }_{i t}$ is the annual software development expense for firms classified as “capitalizers", $\mathrm{MV}_{\mathrm{it}}$ is the $\log$ of market value of firm i three months after end of fiscal year t. BETA $\mathrm{it}_{\mathrm{it}}$ is the firm's CAPM beta, calculated over 100 days before fiscal year end. LAGRET ${ }_{\text {it }}$ is the firm's annual stock return, cumulated from nine months before fiscal t year-end through three months after it. M/ $B_{i t}$ is the firm's market value three months after end of fiscal year $t$ divided by the firm's book value. The right-hand variables $\mathrm{CAP}_{\mathrm{it}}, \mathrm{EXP}_{\mathrm{it}}$, and $\mathrm{EXPCAP}_{\mathrm{it}}$ are scaled by fiscal year $\mathrm{t}$ market value. 


\section{TABLE 7}

Capitalization Intensity and the Quality of Analysts' Forecasts Regressions of Analysts' Forecast Errors of Earnings on

Capitalization Variable and Controls (t-values in Parentheses).

$$
\begin{aligned}
& \text { Models: } \quad \mathrm{AFE}_{\mathrm{it}}={ }_{\mathrm{Y}=87}^{95} \beta_{0 \mathrm{Y}} \mathrm{YR}_{\mathrm{it}}+\beta_{\mathrm{l}} \mathrm{CAP}_{\mathrm{it}}+\beta_{2} \mathrm{MV}_{\mathrm{it}}+\varepsilon_{\mathrm{i}} \\
& \mathrm{MAFE}_{\text {it }}=\underset{\mathrm{Y}=87}{95} \beta_{0 \mathrm{Y}} \mathrm{YR}_{\mathrm{it}}+\beta_{1} \mathrm{CAP}_{\mathrm{it}}+\beta_{2} \mathrm{NUMANA}_{\mathrm{it}}+\beta_{3} \mathrm{AGE}_{\mathrm{it}}+\beta_{4} \mathrm{MV}_{\mathrm{it}}+\varepsilon_{\mathrm{i}} \\
& \mathrm{STDFE}_{\text {it }}={ }_{\mathrm{Y}=87}^{95} \beta_{0 \mathrm{Y}} \mathrm{YR}_{\mathrm{it}}+\beta_{1} \mathrm{CAP}_{\mathrm{it}}+\beta_{2} \mathrm{NUMANA}_{\mathrm{it}}+\beta_{3} \mathrm{AGE}_{\mathrm{it}}+\beta_{4} \mathrm{MV}_{\mathrm{it}}+\varepsilon_{\mathrm{it}}
\end{aligned}
$$

\begin{tabular}{llcrrl}
\hline \hline \multicolumn{1}{c}{ Dependent variable } & $\mathrm{CAP}_{\text {it }}$ & NUMANA $_{\text {it }}$ & $\mathrm{AGE}_{\text {it }}$ & $\mathrm{MV}_{\text {it }}$ & Adjusted R $^{2}$ \\
\hline $\mathrm{AFE}_{\text {it }}$ & 0.288 & - & - & -0.020 & 0.08 \\
MAFE $_{\text {it }}$ & $(36.51)$ & & & $(-12.44)$ & \\
& 0.113 & -0.002 & 0.007 & -0.011 & 0.22 \\
STDFE $_{\text {it }}$ & $(3.77)$ & $(-0.34)$ & $(2.80)$ & $(-7.39)$ & \\
& 0.015 & 0.001 & 0.001 & -0.002 & 0.29 \\
\hline
\end{tabular}

The first regression is based on 28,447 analysts forecast errors (137 independent firms). The second and third regressions are based on 538 firm-years (130 independent firms). The regressions are for the 1987-95 period and include year intercept dummies (not reported). Reported t-statistics are based on White [1980] standard errors.

The dependent variables are: $\mathrm{AFE}_{\mathrm{it}}$ is the absolute value of analyst forecast errors defined as reported EPS minus analyst forecast, deflated by price. $\mathrm{MAFE}_{\mathrm{it}}$ is the firm-specific mean absolute forecast error (to be included in the regression at least three analyst forecasts per firm are required). $\mathrm{STDFE}_{\mathrm{it}}$ is the standard deviation of the individual analyst forecasts around the consensus (to be included in the regression at least three analyst forecasts per firm are required). The independent variables are: $\mathrm{CAP}_{i t}$ is the annual capitalized software costs divided by market value at beginning of year. NUMANA $A_{i t}$ is the natural $\log$ of the number of analysts following the firm. AGE it is the age of the forecast (in days), defined as the earnings announcement date minus the forecast date. $\mathrm{MV}_{\mathrm{it}}$ is the log of the firm's market value at the end of fiscal year $t$. 


\section{FIGURE 1}

THE IMPACT OF SOFTWARE CAPITALIZATION ON REPORTED EARNINGS

Medians of Yearly Impacts on Earnings (Before Development Cost Expensing) of Software Capitalization And the Amortization of the Software Capital

(Numbers in parentheses below the years are the median operating income

plus the expensed development costs, in \$ millions)

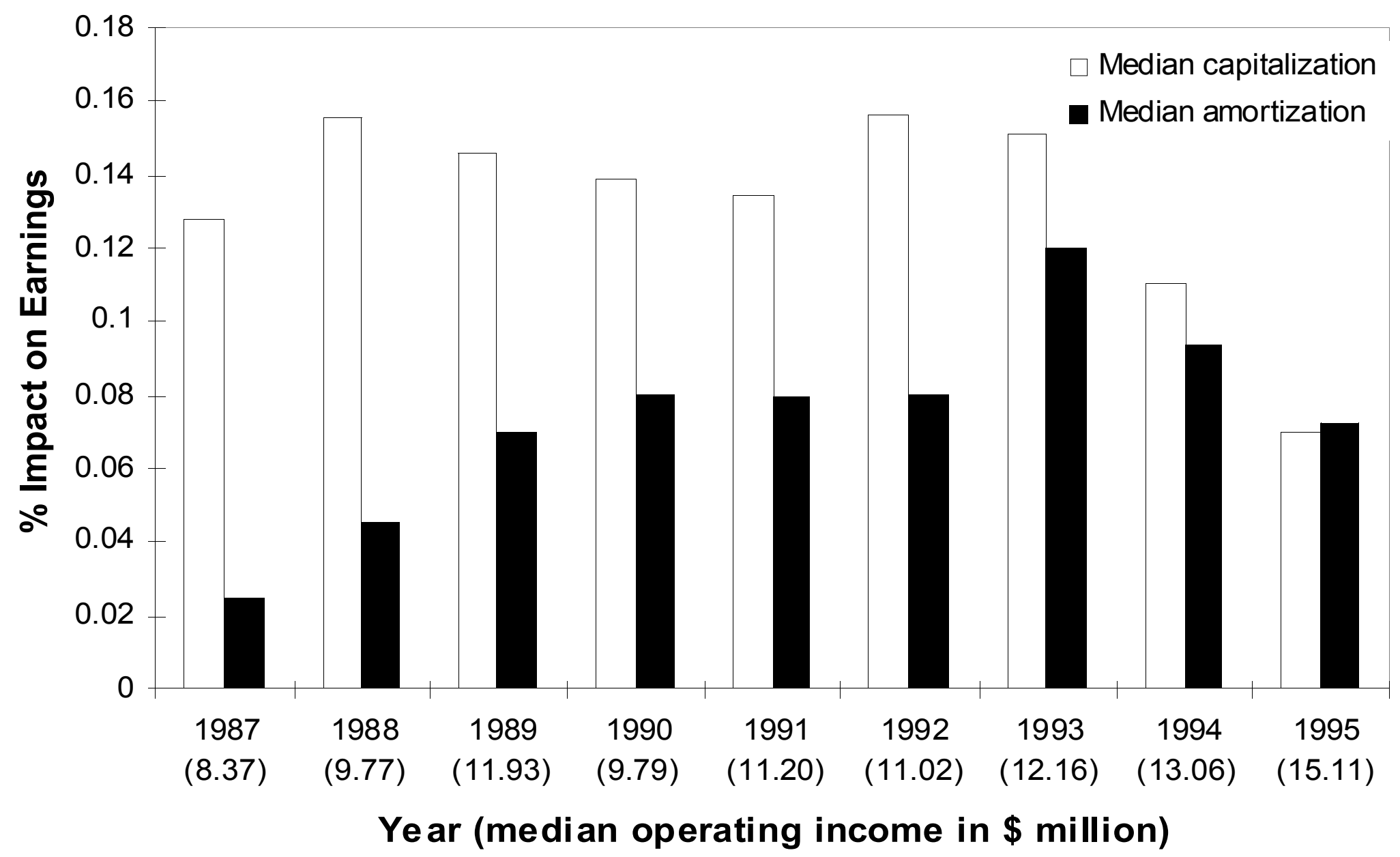


APPENDIX

\section{Summary of SFAS No. 86 (August 1985): Accounting for the Costs of Computer Software to be Sold, Leased, or Otherwise Marketed}

This statement covers only software developed for sale, and not: (1) software developed or purchased for internal use, and (2) software developed for other entities, based on a contractual agreement.

The first stage of software development program starts with the initiation of the software project and ends when technological feasibility is achieved. All costs incurred during this stage are expensed as research and development costs, according to SFAS No. 2.

The conditions specified by SFAS 86 for the establishment of technological feasibility are essentially:

1. The detail program design has been completed, and all the technical requirements are met to produce the software.

2. The enterprise has confirmed completion of the program design and that there are no technological uncertainties concerning development issues.

All development costs incurred during the second stage - - from the establishment of technological feasibility to the date when the software is ready to be released to customers - - should be capitalized as an asset (to be presented on the balance sheet as a long-term asset) and subsequently amortized. This capitalization lies at the core of the current study.

During the third stage - - from ready-to-be-sold to the date of sale - - the enterprise incurs "inventory costs," such as duplicating software masters, developing training material and packaging. These costs are capitalized as inventory on a unit-specific basis and are charged to cost of sales as the products are sold.

The fourth and last stage of software project development starts with the software sale. All costs subsequently incurred (e.g., for maintenance and support) are immediately expensed.

The cumulative capitalized production costs (during stage 2), namely the software asset, are amortized on a product-by-product basis. The greater of the amounts computed by the following two methods should be used: (1) straight-line amortization over the expected useful life of the software product, or (2) the "gross revenue ratio" method, where the ratio of actual software revenues during the year to total estimated revenues in the current and future years, determines the annual amortization.

\footnotetext{
* Based on B. Jarnagin, 1993.
} 
Finally, at the end of each year, the unamortized software asset has to be written down (if applicable) to the net realizable value of the project, defined as the future estimated gross revenues from the sale of the software product minus costs to complete and dispose of it. 


\section{ENDNOTES}

* University of California at Los Angeles and New York University. We acknowledge the helpful comments of Brad Barber, Daniel Bens, Garry Biddle, Robert Herz, Bertrand Horwitz, Robert Holthausen, James Leisenring, Ed Maydew, Krishna Palepu, Michael Williams and Paul Zarowin.

${ }^{1}$ The essence of this statement is presented in the appendix.

${ }^{2}$ Software capitalization starts upon the establishment of technological feasibility of the product under development. The preceding research costs are fully expensed; see appendix.

${ }^{3}$ For ADAPSO's position on software capitalization, as well as the heated debate on the merits of the 1985 software capitalization exposure draft (e.g., over 200 comment letters sent to the FASB), see FASB Public Record [1985].

${ }^{4}$ This accounting practice has received wide media attention, see recent articles in the Wall Street Journal [December 2, 1996 and may 7, 1997], Briloff's article in Barron's [December 23, 1996], Institutional Investor [March 1997], and The New York Times [July 5, 1998].

${ }^{5}$ Following is our analysis of the 50 deleted companies. The financial data of nine companies were not available on Laser Disclosure. Eight companies did not engage in software production. Of the 33 remaining firms, 23 capitalized software development costs and ten fully expensed such costs, a ratio of capitalizers-to-expensers similar to that of our sample. The 33 deleted firms were public an average (median) of 18.1 (18.0) months. Twenty companies were purchased (18 in pooling transactions and two in purchase transactions) and 13 companies went bankrupt. In section 5.1 we comment on the effects of including the deleted companies on our regression results. ${ }^{6}$ We identified 58 software asset write-offs by our sample companies. Given this small number, we did not examine the write-offs separately.

${ }^{7}$ There are 163 companies in our sample. However, since we require a minimum of three-year data, there are fewer than 163 firms in each sample year (see $\mathrm{N}$ column in Table 1).

${ }^{8}$ On the industry shakeout phenomenon, see for example, Gort and Klepper [1982] and Klepper and Graddy [1990].

${ }^{9}$ The mean ROE series is influenced by 10 very small firm-year observations ( 8 independent firms) with a mean (median) book value of $\$ 1.24$ million ( $\$ 1.21$ million). Removing those 10 firm-years from the sample considerably reduces fluctuations in the mean ROE.

${ }^{10}$ Deloitte and Touche [1996, p.1] also note that firms in the "younger" segments of the industry (e.g., software for education and entertainment) and recent IPOs tend to capitalize less than mature companies. 
${ }^{11}$ It is relatively easy for software companies to justify immediate expensing. For example, SFAS 86 requires that the expected net realizable value of the project exceed the capitalized value of the software asset. Given the subjectivity in assessing expected net realizable values, it seems that managers preferring immediate expensing can easily justify this approach.

${ }^{12}$ Following are descriptions of the four product-types taken from financial reports: Engineering -- "The firm designs, produces and markets proprietary computer software products for use in computer aided engineering." Education and Entertainment -- "Develops, publishes, manufactures and distributes high quality educational software products for home and school use." Business Applications -- "Develops, licenses and markets system software products, including monitoring and event management tools, back up and recovery products, and data-base administration tools to improve performance, reliability and manageability of large scale mainframe systems software, open systems data bases and various other systems." PC Packaged Software -- "Designs, develops, and markets systems and application software which enables users to work with professional creative tools, assemble illustrations, image and text into fully formatted documents, output documents directly to any kind of printing device and distribute documents on paper, video or compact disc, over an e-mail system, corporate network, on-line service, or the internet."

${ }^{13}$ A period has a minimum of three years. Eight firms expensed in the first period and capitalized in the subsequent period and four firms capitalized in the first period and expensed in the second period.

${ }^{14}$ We obtained similar regression estimates when the dependent variable was scaled by sales and when we employed a logit analysis ( 1 for capitalizers and 0 for full expensers) instead of the regression analysis in Table 2.

${ }^{15}$ The following variables were also included in various versions of the regression analysis of Table 2 and were found to be insignificant: Altman [1968] measure of financial distress, past volatility of returns and level of earnings.

${ }^{16}$ Our results are qualitatively the same when we include the level of AMRT instead of the change.

${ }^{17}$ However, expression (2) is the one recommended by Barth and Kallapur [1996] to deal with scale issues: "the most effective remedy [control for scale] is to include a scale proxy as an independent variable and report inferences based on White standard errors.” (p.556).

${ }^{18}$ The Z1-statistic, which assumes residual independence, is $\left.(1 / \sqrt{ })_{j=1}\left(t_{j} / \sqrt{K_{j} /\left(k_{j}\right.} 2\right)\right)$ where $t_{j}$ is t-statistic for year $\mathrm{j}, \mathrm{k}_{\mathrm{j}}$ is degrees of freedom, and $\mathrm{T}$ is number of years. The Z2-statistic, which accounts for cross-sectional 
and temporal residual dependence, is mean t-statistic / (standard deviation of t-statistics / $\sqrt{T-1}$ ) (see White [1984]).

${ }^{19}$ All the reported t-statistics are based on White [1980] standard errors. Diagnostic statistics shows that no multicollinerity is prevalent in our data. The Durbin-Watson test indicates that at the $1 \%$ significance level the hypothesis of autocorrelation of the residuals can be rejected.

${ }^{20}$ Size-adjusted returns were taken from the CRSP decile file, and are provided separately for NYSE and NASDAQ firms.

${ }^{21}$ Eccher [1995] reached a different conclusion: software capitalization is not value-relevant, while amortization of the software asset is relevant. The different conclusion appears to be mainly due to sample size and period (although the methodology of the two studies is also substantially different). While Eccher's sample period is 1988-1992 (303 firm-years), ours is 1987-1995 (862 firm-years). Furthermore, Eccher reports that 9\% of her sample firms fully expensed development costs, while $20 \%$ of our sample are full expensers.

We estimated Eccher's basic regression on our data: market-to-book ratio regressed on revenue growth, R\&D expensed, R\&D capitalized, expected cash flows and percentage write-offs. While Eccher finds the coefficients of $R \& D$ expensed and R\&D capitalized very close (leading to her conclusion that $R \& D$ capitalization is not valuerelevant), we find the two coefficients in our sample significantly different. The estimated coefficient of the R\&D expense is 0.450 (p-value $=0.073)$, while the coefficient of the capitalized $R \& D$ is $3.940(p$-value $=0.001)$. The difference between these coefficients is significant at the 0.01 level. We use in this footnote the term R\&D to conform with Eccher's study, while in our paper we use the term "software development cost."

${ }^{22}$ This test examines directly the Software Publishers Association claim: "We do not believe that software development costs are a useful predictive factor of future product sales." (SPA letter to the FASB, [March 1996, p.4]).

${ }^{23}$ In the top regression (one year ahead operating income) the difference between the coefficients of $\triangle \mathrm{CAP}$ and $\triangle \mathrm{EXP}$ is insignificant, but both coefficients are significantly larger than the coefficient of $\triangle$ EXPCAP. In the other three regressions, the coefficients of $\triangle \mathrm{CAP}$ are significantly larger (at the 0.01 level) than the coefficients of $\triangle \mathrm{EXP}$ and those of $\triangle \mathrm{EXPCAP}$.

${ }^{24}$ For example: 
“And, the last point, which I think is a critical point from my view is that it [software capitalization] overall would reduce the quality of earnings. It would make it more difficult for me to assess which companies are doing well or not.” (James Mendelson, software analyst at Morgan Stanley, FASB public hearings, May 2-3, 1985, p.1142 of the Public Record.)

${ }^{25}$ Recall that SFAS 86 is intended to enable investors to make such a distinction.

${ }^{26}$ We also estimated regression (4) for individual years 1985-1994 (not reported in Table 6). The across-year significance tests indicate the coefficient of EXP is positive and statistically significant at the 0.01 level in all three subsequent years (in Table 6, pooled results, the coefficient is insignificant in the third year).

${ }^{27}$ The decreasing bars in 1993-1995 in figure 1 may convey the impression of a fast falling rate of software capitalization and amortization. This, however, is not the case. As indicated by the bottom numbers in parentheses (to the right of the year), the decreasing capitalization and amortization impact on earnings during 1993 95 was mainly due to the increasing denominator - operating income before development costs expensing. Operating income increased at the median from \$11.02 million in 1992 to \$15.11 million 1995.

${ }^{28}$ We do not claim that our conjecture about the diminishing appeal of capitalization in the 1990s is the only motive of software companies to abolish SFAS 86 . There may be, for example, validity to the SPA arguments that "the time permitted for a successful software development cycle has been significantly shortened ... [and] the technical complexity of the software being developed today have significantly increased the uncertainty of successful completion of development projects." (SPA letter, March 1996). However, we have no way to empirically examine these arguments, nor did the SPA provide support for them.

${ }^{29}$ For a summary of analysts' opposition to SFAS 86, see The Financial Analysts Federation's May 13, 1985 letter to the FASB [the Public Record, pp. 776-777]. Currently, such opposition is expressed in the AIMR (1993) report: "We are not enamoured of recording self-developed intangible assets unless their values are readily apparent.” [p. 50-51].

${ }^{30}$ The sample data on the relative volatility of software development expenses with and without capitalization are consistent with this conjecture. Specifically, we computed for capitalizing firms with at least six years of data in the sample the firm-specific variance of total annual development costs and the part of the cost that was expensed. By our conjecture, the former (which is analogous to the software expense of full expensing firms) should be smaller than the latter. This indeed is the case; the sample mean (median) of the variances is $0.0957(0.0630)$ for total development costs and $0.1319(0.0804)$ for the expensed part of development costs (i.e., total cost minus 
capitalization). The difference in the means (medians) is significant at the $0.07(0.01)$ level. Capitalization is thus associated with an increased variance of the portion of software development cost which is expensed.

${ }^{31}$ As a first cut, we computed the sample mean and median of analyst forecast errors for software capitalizing and full expensing firms. The mean (median) errors for "capitalizers" are: $0.010(0.0017)$ and for "expensers": 0.0079 (0.0006). Thus consistent with our conjecture, the forecast errors for "capitalizers" are larger than those of full expensers (the difference in the means is not significant at conventional levels, while that of the medians is significant at the 0.01 level). The above unconditional differences in the quality of forecasts may, of course, be due to factors unrelated to capitalization (e.g., firm size), hence we perform the regression analysis reported in Table 7. ${ }^{32}$ Other capitalization intensity measures - annual capitalization to total development costs and the ratio of the capitalized asset to equity - yield results similar to those reported in Table 7.

${ }^{33}$ See Mikhail et al. [1997] for the use of these control variables and references to original studies. 